\title{
Effects of Computer Assisted Instruction in Nupe Language on Pupils' Achievement in Mathematics in Bida Local Government Area of Niger State, Nigeria
}

\author{
Dr. Dantani Ibrahim Wushishi ${ }^{1}$, Dr. M.A Yusha'u ${ }^{2}$ \& Hassan Usman ${ }^{3}$ \\ ${ }^{I}$ Department Of Science Education, Federal University of Technology, Minna-Nigeria \\ ${ }^{2}$ Department of Science and Vocational Education, Usmanu Danfodiyo University, Sokoto-Nigeria \\ ${ }^{3}$ Department Of Mathematics, Niger State College Of Education, Minna-Nigeria
}

\begin{abstract}
The study investigated the effects of computer assisted instruction package in Nupe Language on primary school pupils in Bida local government area of Niger State. Two research questions and two hypotheses were formulated for the study. The design adopted for the study was quasi experimental. Two hundred and two (202) primary school pupils from four selected schools in Bida local government area were used as research sample. The experimental group was exposed to computer assisted instruction package in Nupe language while the control group was taught the same topics with conventional method in English Language. A 40 item Primary School Mathematics Achievement Test (PSMAT) with a reliability coefficient of 0.80 was used to collect data for the study. The data were analyzed using Analysis Of Variance (ANOVA). The hypotheses were tested at 0.05 level of significance. The findings of the study showed that Pupils taught mathematics with computer assisted instruction package in Nupe language performed better than those taught with conventional teaching method and gender has effect on their mathematics achievement scores. It was recommended that mathematics teachers should continuously use computer packages in teaching mathematics as it guarantees improvement in students' achievement in mathematics.
\end{abstract}

Keywords- Computer Assisted Instruction, Conventional Method, Mathematics Achievement

\section{Introduction}

Mathematics has continued to play significant role in Nigeria's national development. Mathematics educator stated among other things that there is no other subject that has greater application than Mathematics (Odogwu, 2002). Today more than ever, the fields of knowledge are dependent on Mathematics for solving problem, stating theories and predicting outcome (Odili, 2006). Keith (2000) reported that today, scarcely any aspect of our lives is not affected, often in fundamental and far reaching way, by the product of Mathematics. When one think of technological and communications infrastructure that under girds our lives, you realize that we are in fact in a "Mathematical universe". In the National Policy on Education (NPE) (FGN, 2004) Mathematics is one of the compulsory subjects in the basic education curriculum. The importance accorded Mathematics in the curriculum reflects accurately the recognition of the vital role it plays in contemporary society.

Researches of Kurumeh and Imoko, (2008) revealed low academic achievement of students in mathematics at all levels of education in Nigeria from primary school (Basic education) to secondary school. Also pupils and secondary school students complained about mathematics as being difficult. This means that mathematics foundation is very weak in primary school level and is carried forward to Junior and senior Secondary School levels which has culminated to poor academic achievements in Senior School Certificate of Education (SSCE), West Africa Examination Council (WAEC) and National Examination Council (NECO). Table1 shows the result for five consecutive years. The record is specifically the results released by West African Examination council (WAEC) for candidates with five credits and above including Mathematics and English, between the year 2006 and 2010.

TABLE 1: Percentage of Candidates that passed with five credits and above including Mathematics and English Language in WAEC

\begin{tabular}{llc}
\hline Year & Total Candidate Enrolled & \% of Candidates with Credit and above \\
\hline 2006 & $1,171,423$ & 22.15 \\
2007 & $1,267,764$ & 20.71 \\
2008 & $1,354,478$ & 26.68 \\
2009 & $1,357,053$ & 26.56 \\
2010 & $1,315,786$ & 23.36 \\
Average \% Pass & & $\mathbf{2 3 . 8 9}$ \\
\hline
\end{tabular}

Source: Daily Trust, Thursday December 29,2011 
From Table 1 it will be observed that the average percentage pass of 23.89 WAEC results from 2006-2010 is not encouraging. Recalling from experience of his involvement in the marking of mathematics at WAEC level Adeniyi (1988), stated that it is enough to get anyone sorrowful at the state of the subject in Secondary School level today. Many candidates, according to him, submit their answer scripts without writing anything in them. Some merely recopy the questions, while a high percentage of those who tried to write at all obtain low or failure grades. Obodo (1997) also stated that there is a low interest in the study of mathematics and mathematics related disciplines at all level of education in Nigeria, Students dislike or hate mathematics. Consequently, he explained, that in Nigeria, many students are not studying courses that they wants to study due to their negative attitude towards mathematics. For instance, many candidates have interest in choosing Engineering, Medicine and Accountancy as courses they would like to study, but they could not study such courses because they achieved poorly in mathematics. Many researches have come out with useful results on the causes of student's poor academic achievement in mathematics in both primary and secondary schools. For instance, Odili (2006) classified these problems into three main classes as mathematical, pedagogical and psychological. Under pedagogical problems, he identified factors such as inadequate qualified mathematics teachers, inadequate instructional materials for teaching mathematics and persistent usage of conventional methods of teaching in schools at all levels. According to Obodo (1997) factors responsible for students' poor performance in mathematics at primary and secondary school levels are inappropriate application of methods of teaching the students. It is also observed by the chief examiner of West African Examination Council (WAEC) that, the problem affecting mathematics achievement can be related to teacher's method of presenting the content of the curriculum to students (Chief Examiner, 2002).

Many science educators have continued their search for alternative and more appropriate teaching method for science instruction (Orji \& Ebele, 2006). Research efforts have revealed that there are considerable language difficulties and too much theoretical expressions by the mathematics teachers in the teaching and learning of mathematics (Fatima, 2006). According Usman (2006) there are considerable language difficulties in the learning of mathematics even in countries such as India, china, Japan etcetera where children are fortunate to learn mathematics in their mother tongue throughout their school days. For instance, Fafunwa, (1975); Usman and Umo, (2006) in their respective studies investigated the effect of mother tongue on the achievement of pupils in mathematics where the experimental group were taught using the mother tongue while the control group were taught using conventional language of instruction. The result revealed that the experimental group performed better than the control group after the treatment.

Perhaps, one particular innovation that may likely facilitate learning among primary school pupils is the exploration of new technologies that can bring knowledge in the real-life experiences to their door steps (Ajewole \& Ogunlusi, 2003). Inyana (2002) cited in Akubuilo and Ndubuiza (2003) maintained that computer are today being used in extremely versatile way to aid the understanding of the wide varieties of subjects, most especially the sciences and technology subjects as well as mathematics. Many researches have been carried out on the effectiveness of Computer Assisted Instruction (CAI). According to studies carried out by Kausar, Chudhry and Gujjar (2008); Tabasun in Owusu, (2009); Harrison in Owusu (2009) they revealed that students that were instructed through CAI performed better than those who were instructed through conventional teaching strategy such as lecture method. While other researchers such as Delafuente, Araujo and legg (1998); Owusu (2009); Jenks and springer (2002) affirmed that CAI has little or no effect on students academic achievement.

Researches on gender and gender related issues in Mathematics are inconclusive. Achuonye (2009) found significant difference in academic achievement of males and females students taught using CAI in favour of male students. Yusuf and Afolabi (2010); Bello cited in Achuonye, (2011); Huynh et., al (2005) reported that gender has no influence on performance of males and females pupils exposed to CAI.

In view of the foregoing discussion, this study sought to determine the effects of CAI on pupil's achievement in mathematics at primary school level. Specifically, to determined the effects of CAI in Nupe language on pupils achievement in mathematics in Bida Local Government Area of Niger State, Nigeria.

\section{Statement Of The Problem}

Several studies have reported poor students' academic achievement in mathematics despite the importance attached to the subject in the national policy on education (Odili, 2006). The students' performances continue to deteriorate year after year (Odili, 2006). This has become a source of concern to all stakeholders in education in Nigeria, because no teacher in Nigeria that teaches mathematics at any level can prove that all is well in the teaching of the subject. Those who teach subjects requiring the application of mathematics complained of the challenges they face, such as lack of interest in the subject as a result of insufficient language of expression, (Idoko, 2009). Furthermore mathematics teaching in Nigeria today still follows the traditional pattern such as lecture method etcetera which has been identified as being ineffective method in ensuring students participation in the lesson. (Odili, 2006). Non-utilization of necessary techniques in teaching 
mathematics is another contributing factor (Odili, 2006). It is against this background that this study investigated the effects of Computer Assisted Instruction (CAI) in Nupe language on pupils' achievement in mathematics.

\section{Objectives Of The Study}

The following were the research objectives for this study

1. To develop an instructional package in mathematics in Nupe language

2. To find out the effects of Computer Assisted Instruction (CAI) in Nupe language on the mathematics achievement of primary school pupils.

3. To examine whether there is any difference in mathematics achievement of males and females primary school pupils taught using CAI

\section{Research Questions}

The study provided answers to the following research questions

1. Is there any difference in the academic achievement of primary school pupils taught mathematics using computer assisted instruction in Nupe language and those taught with conventional teaching method using English language.

2. Is there any difference in the academic achievement of males and females primary school pupils taught mathematics using computer assisted instruction in Nupe language and those taught with conventional teaching method using English language?

\section{Null Hypotheses}

The following two Null hypotheses were tested at 0.05 significant level

$\mathrm{HO}_{1}$ : There is no significant difference between the academic achievement of primary school pupils taught mathematics using computer assisted instruction package in Nupe language and those taught with conventional teaching method using English language.

$\mathrm{HO}_{2}$ : There is no significant difference between the academic achievement of males and females primary school pupils taught mathematics using computer assisted instruction package in Nupe language and those taught with conventional teaching method using English language.

\section{Scope Of The Study}

This study made use of a developed CAI package in Nupe language and find its effect on primary pupils' achievement in some selected mathematics concepts in Bida Local Government of Niger state. The study was conducted in four primary schools specifically primary two pupils were involved, this is because, at this level medium of instruction shall be the language of the environment for the first three years, English shall be taught as a subject (FGN, 2004). Hence the concepts treated were selected from their curriculum. The aspect of mathematics concepts focused is number and numeration, basic operation of addition, subtraction, multiplication, division and descriptive geometry. It also examines the influence of gender on students' achievement when taught using CAI package.

\section{Methodology}

The study employed a quasi-experimental design a pre-test, post-test non-equivalent group design which entails the use of non-randomized group where the researcher cannot randomly sample and assign subjects because intact classes were used to administer the treatment. It is not possible to randomize the subject of the study without disrupting the school setting, therefore four separate intact classes were used, two for experimental group and two for control group. Population and Sample

Primary two (2) pupils of all the fifty three (53) primary schools in fourteen (14) wards of Bida local government area constitute the population of the study with total population of four thousand four hundred and thirty $(4,430)$ pupils (LGEA, 2010). It is from this population that two hundred and two (202) primary two pupils were selected, consisting of one hundred and twenty five (125) male and seventy seven (77) female. The distribution of sample by gender and sampled school is shown in Table 2 . 
TABLE 2: Distribution of Sample by Gender and Schools

\begin{tabular}{llllccc}
\hline S/NO & Name of wards & Name of schools & Population & Male & Female & School Sampled \\
\hline 1 & Chaniyan & Ibrahim Tako P.S & 259 & 31 & 21 & 52 \\
2 & Bariki & Sabon Gida P.S & 165 & 27 & 19 & 46 \\
3 & Masaba & Ndazabo P.S & 154 & 36 & 20 & 56 \\
4 & Wadata & Masaba P.S & 258 & 31 & 17 & 48 \\
Total & $\mathbf{4}$ & $\mathbf{4}$ & $\mathbf{8 3 6}$ & $\mathbf{1 2 5}$ & $\mathbf{7 7}$ & $\mathbf{2 0 2}$ \\
\hline
\end{tabular}

Source: LGEA Bida,(2010)

\section{Instruments}

Two instruments, the Primary School Mathematics Achievement Test (PSMAT) and Computer Assisted Instruction Package in Nupe Language (CAIPNL) were developed by the researchers with the assistance of a professional programme developer with mathematics orientation were used for the study.

The PSMAT and CAIPNL were validated by a team of four experts two each from Federal University of Technology (FUT) Minna and Usmanu Danfodiyo University, Sokoto respectively. Fifty five (55) PSMAT submitted for validation were modified on the basis of suggestions and recommendations of the validators. The final fourty (40) PSMAT items were used for the study. The reliability coefficient for the PSMAT was found to be 0.84 after using test retest method. The tests were administered to 202 pupils by the researcher with the help of research assistants. The data collected were used for testing hypotheses. The F-test statistics was used to test the two null hypotheses.

TABLE 3: Results of ANOVA Test for Experimental and Control Group on Pre-test

\begin{tabular}{llllll}
\hline $\begin{array}{l}\text { Source of } \\
\text { Variation }\end{array}$ & $\begin{array}{l}\text { Sum of } \\
\text { Squares }\end{array}$ & Df & $\begin{array}{l}\text { Mean } \\
\text { Square }\end{array}$ & Fcal & Sig Level \\
\hline Between Groups & 0.10 & 1 & 0.10 & 0.002 & 0.990 \\
Within Groups & 12337.876 & 200 & 61.689 & & \\
Total & 12337.886 & 201 & & & \\
\hline
\end{tabular}

*Not significant at 0.05

Table 3 indicates that there is no significant difference in mathematics achievement by pupils from the experimental group and pupils from the control group because calculated 0.990 significant level is greater than 0.05 standard alpha level ( $>>0.05$ ). This means that the pupils in the two groups exhibited approximately the same entry behavior before the treatment.

Hypotheses one $\left(\mathbf{H}_{\mathbf{O} 1}\right)$ :There is no significant difference between the academic achievement of primary school pupils taught Mathematics using computer assisted instruction package in Nupe language and those taught with conventional teaching method using English language

TABLE 4: Results of ANOVA Test for Experimental and control group on post-test

\begin{tabular}{llllll}
\hline $\begin{array}{l}\text { Source of } \\
\text { Variation }\end{array}$ & $\begin{array}{l}\text { Sum of } \\
\text { Squares }\end{array}$ & Df & $\begin{array}{l}\text { Mean } \\
\text { Square }\end{array}$ & Fcal & Sig Level \\
\hline Between Groups & 54589.767 & 1 & 54589.767 & 552.304 & 0.000 \\
Within Groups & 19768.000 & 200 & 98.840 & & \\
Total & 74357.67 & 201 & & & \\
\hline
\end{tabular}

*Significant at 0.05 level

Table 4 indicates that there is significant difference between the achievement scores in Mathematics by pupils from the Experimental Group and pupils from the Control Group because 0.000 significant level is less than 0.05 alpha level $(p<0.05)$. Therefore, hypothesis one is rejected. This means, there is significant difference in the academic achievement of pupils taught using Computer Assisted Instruction Package in Nupe language and those taught with conventional teaching method using English language. The significant difference is in favour of Pupil taught using CAIPNL.

Hypotheses $\mathrm{HO}_{2}$ : There is no significant difference between the academic achievement of males and females primary school pupils taught mathematics using computer assisted instruction package in Nupe language and those taught with conventional teaching method using English language.

TABLE 5: Results of ANOVA Test on Gender

\begin{tabular}{|c|c|c|c|c|c|}
\hline $\begin{array}{l}\text { Source of } \\
\text { Variation }\end{array}$ & $\begin{array}{l}\text { Sum of } \\
\text { Squares }\end{array}$ & Df & $\begin{array}{l}\text { Mean } \\
\text { Square }\end{array}$ & Fcal & Sig Level \\
\hline Between Groups & 64517.424 & 3 & 21505.808 & 540.076 & 0.000 \\
\hline Within Groups & 7645.392 & 192 & 39.820 & & \\
\hline Total & 72162.816 & 195 & & & \\
\hline
\end{tabular}

*Significant at 0.05 level 
From Table 5 all the four test groups were compared on post test in terms of differences in mathematics achievement scores by Gender. The result indicates that there is significant difference between the scores of males and females pupils of the tested groups because 0.000 significant level is less than 0.05 alpha level of significance $(\mathrm{p}<0.05)$

Since the ANOVA indicates that there is significant difference among the four groups in Table 5, there is the need to find out which group(s) is responsible for the difference using Ducan post hoc test.

TABLE 6: Duncan post hoc test on Comparison of Achievement Scores by Gender

\begin{tabular}{lll}
\hline Test code & S & Subset for alpha $=0.05$ \\
\cline { 2 - 3 } & 1 & 2 \\
\hline
\end{tabular}

Female exp grp $\quad 39 \quad 57.3846$

\begin{tabular}{lrl} 
Male exp grp & 59 & 76.1864 \\
\hline
\end{tabular}

Table 6 indicates the mean scores of experimental groups. So, the mean Scores obtained from male group was significantly higher than the female group $(76.19>57.39)$. It is to be noted that significant difference is in favour of male gender.

\section{Summary Of Findings}

The following are the summary of the research findings:

1. Pupils taught mathematics with the use of computer assisted instruction package in Nupe Language performed better than those taught mathematics with conventional teaching method.

2. The performance of pupils in mathematics when they are taught with computer-assisted instruction is gender dependent. The study indicates that there is statistical significant difference in the mathematics scores in favour of male pupils.

\section{Discussion}

From Table 3, the results of Analysis of Variance (ANOVA) on the achievement of students taught Mathematics using computer assisted instruction in Nupe language indicates that there is no significant difference between the achievement of the experimental and control groups on pre-test. This showed that the pupils in the two groups had equivalent mathematics background as entry behavior. However, the finding indicated that there is significant difference in the academic achievement of pupils taught using Computer Assisted Instruction Package in Nupe Language and those taught with conventional method using English Language. In other words there is significant difference in favour of those taught with CAIPNL. This finding agree with the earlier finding of Tabassum in Owusu (2009) who found that students who used CAI scored significantly higher in mathematical concepts and computation than students who went through the traditional approach. This reveals that the students that were instructed through CAI performed better on the mathematical concepts as compared to those students who were instructed through teaching strategies such as lecture or question and answer method.

The findings of Harrison in Owusu (2009) on computer assisted instruction in basic arithmetics concept also corroborated the findings of this study. The result reveal that students who recieved computer assisted instructions show greater increase in their achievement scores in multiplication and subtraction than students who recieved traditional mathematical instructions. The study also reveals that CAI is capable of improving students achievement. The findings of this study also corroborated the findings of Kausar, choudhry and Gujjar (2008) who revealed that CAI proved to be significantly superior to classroom lecture in terms of achievement in knowledge, analysis and synthesis of the Bloom's taxonomy when they conducted a comparative study to evaluate the effectiveness of computer-assisted instruction versus classroom lecture for computer science students. In terms of evaluation and application skills, they found that CAI proved to be very much effective in increasing those skills as compared to classroom lecture. This study suggests that CAI is able to improve students achievement and performance. In the same vein, this study supported the position of Usman and Umo (2006) on the effect of mother tongue (Igbo) on the achievement of lower universal basic education pupils in mathematics. Their findings revealed that pupils who were taught in Igbo Language performed better than those taught with conventional method in English Language. The work of Fafunwa (1975) on Ife-six year primary science project also showed that pupils taught in mother tongue (Yoruba), not only excelled in Yoruba, but did better than pupils who were taught in English Language. This study is also supportive of Fafunwa (1975) assertion. 
However, the findings of this study are in contrast with the findings of Delafuente, Araujo and Legg (1998) who reported no significant difference in final exam score between students taught by CAI and those taught by the traditional instruction. The finding of Owusu (2009) on a comparative study of traditional instruction modes with CAI modes indicated that the results suggested that CAI is not as useful for instruction as previously believed because students in the CAI group did not perform better than those in traditional instruction mode. This study has proved that the use of CAIPNL is very effective in contrast to( Owusu, 2009) who proved CAIPNL to be ineffective.

The result shows that there is significant difference in the achievement scores of both males and females pupils taught CAIPNL and those taught with lecture method in English Language. Ducan test used as post hoc to locate the observed significant difference indicated that there was significant difference between males and females pupils exposed to CAI in favour of male pupils. This finding is in agreement with the finding of: Spotts et al (1997) Achuonye and Olele (2009) who noted that there is significant difference between males and females pupils exposed to CAI. Huynh et., al (2005) found that there is no statistical significant validating difference in the pattern of online interaction between males and females students. Also Yusuf and Afolabi (2010) Bello cited in Achuonye (2011) noted that gender has no influence on performance of males and females pupils exposed to CAI . These were however disapproved by the result of this study which showed that the male gender achieved better scores with CAIPNL than the female gender.

\section{Conclusion}

Based on the findings of this study it was concluded that: Computer assisted instruction significantly enhanced the achievement of learners (pupils) because those pupils taught using CAIPNL performed significantly better than those taught using conventional teaching method and also the study indicates that there is statistical difference between males and females mathematics achievement scores in favour of males pupils' taught with CAIPNL

In view of the findings, it was recommended that:

\section{Recommendations}

1. Teachers should be trained in the use of computer application packages for teaching through workshops, seminars and induction courses.

2. Government and stakeholders in Education should provide functional computer laboratories equipped with adequate backups, equipments and power supply to boost teaching and learning with computer applications.

3. The use of mother tougue should be adopted in teaching Mathematics at all levels of primary education and writers should be encouraged to write primary school Mathematics textbooks in the language of the environment(Mother Togue).

\section{References}

[1]. Achuonye, K. A \& Olele C.N (2009). Internet using pattern of Nigerian Teacher-Trainees: Implication for teacher education in Nigeria. Journal of Science Teachers Association of Nigeria, 44(1\&2): 103-108.

[2]. Achuonye, K. A (2011): Using Computer in science class: The interactive effect of gender. Journal of Africa studies and Development 3(7) 131-134. Retrieved on 24/10/2011 from http://www.academicjournal.org/JASD

[3]. Adeniyi, N. E (1988). Mathematics in secondary schools. Abacus, a Journal of Mathematics

[4]. Ajewole G. A (2003). Information and communication Technology and science Technology and Mathematics Education: Implication for primary schools. STAN proceeding of the $44^{\text {th }}$ Anniversary Conference 2003.

[5]. Akubuilo, D.U \& Ndubuiza (2003). Using information and Technology ( ICT) to enhance learning in Science Technology and Mathematics Education in our secondary schools. STAN proceeding of $44^{\text {th }}$ Annual conference 2003.

[6]. Ardo, G.V \& Samuel, A.D (2006). The effect of mother tongue in learning of integrated science concept: A case study of children in Nigeria. Sokoto Educational Review 8(2) p85.

[7]. Azuka, F. N (2003).Enhancing students performance, using computer aided instruction (CAI) in tertiary institutions. STAN Proceeding of the $44^{\text {th }}$ annual Conference

[8]. Chang, C.Y. (2000). Enhancing tenth graders' earth-science learning through computer-assisted instruction. Journal of Geosciences Education, 48, 636-641.

[9]. Daily Trust 2011 Captioned: Why Candidates fail to gain admission pg 46

[10]. Delafuente, J .C., Araujo, O.E., \& Legg, S.M. (1998). Traditional lecturer format compared to computer-assisted instruction in pharmacy calculations. American journal of n.npharmaceutical Education. Spring. Pp. 1-8.

[11]. Elizabeth, O. (2004). The use of Mother Tongue in Primary Science teaching: A Theme of Democratic Reform. A pepper presented at the first National conference of school of art and social sciences at the Federal college of Education kontagora $26^{\text {th }}-30$ April, 2004.

[12]. Fafunwa, A. B, Macauley, Iybode, \& Sokoya, Funso (1989). Education in mother tongue: The Ife primary education Research project 1970-1978. Ibadan Upl

[13]. Fatima Y.I (2006). Effect of using Computer Assisted Instruction in learning statistics in selected Senior Secondary Schools in Minna Niger State. Unpublished M.Tech Thesis Federal University of Technology Minna.

[14]. Harrison, N. (1993). The effects of Drill-and-Practice Computer Instruction on Learning Basic mathematics. Journal of Computing in Childhood Education 3, 349-356.

[15]. Huynh M.Q, Lee J, Schuldt B.A (2005). The insiders' perspective: A focus group study on Gender issues, in a computer supported collaboration learning environment. J.Inf. Technol.Educ., Retieved on 13/09/2011 from http://jite.org/document/vol4/v4p237-255 Huynh 14.ptd 
[16]. Idoko, J. E (2009). Correlation of student O'level Entry Grade in Mathematics and performance in National Diploma in Engineering, Kaduna Polytechnic Nigeria. An Unpublished M.Tech thesis federal University of technology Minna.

[17]. Jenks, M. S. \& Springer, J.M (2002). A view of the research on the efficacy of CAI? Electronic Journal for the Integration of Technology in Education. 1.(2). 43-58.

[18]. Keith, D (2000). The four faces of mathematics. Learning Mathematics for a new century. 2000 year book National council of Teachers of Mathematics (NCTM).

[19]. Kurumeh, M.S \& Imoke B. I (2008). Universal Education: A way forward for the Development of primary school pupils in Mathematics Education. ABACUS, 33(1) p49-56.

[20]. National Policy on Education (NPE,2004). Nigeria Educational Research and Development council Press. Lagos, Nigeria.

[21]. Obodo, G.C. (1997). Principle and practice of mathematics Education in Nigeria. General studies division, Enugu state university of Science and Technology Enugun.

[22]. Odogwu, H.N (2002). The Mathematics Teacher factor in the achievement of the goal of the UBE, ABACUS.27(1) p72-79.

[23]. Odili G.A (2006). Mathematics in Nigeria secondary school - A Teaching perspectives. Lagos Rex Charles and Patric Limited.

[24]. Owusu K.A (2009). Effect of Computer Assisted Instruction on Senior High School students' Achievement in Biology. An unpublished M.Ed Thesis University of Cape Coast.

[25]. Tabassum, R. (2004) Effect of computer Assisted Instruction (CAI) on the secondary school_student achievement in science. Ph. D Thesis, University of Arid Agriculture, Rawalpinda, Pakistan, Retrieved on 20/04/08 Prr.hec.gov.pk/thesis/235.pdf.

[26]. Usman K.O \& Umo U. C (2006). Effect of mother tongue (Igbo) on the achievement of lower Universal Basic Education (UBE) Pupils in mathematics. Journal of science Teachers Association of Nigeria. 41(1) p89-93.

[27]. West Africa Examination Council (WAEC), (2002). The chief examiners report for the May/Jun 2002 SSCE Mathematics.

[28]. Yusuf M.O. \& Afolabi A.O. (2010). Effect of computer assisted instruction CAI on secondary school students' performance in Biology. The Turkish Online ournalof Educational Technology., 9(1): 62-69. Retrieved from http://www.tojet.net/article/918/ptt./ $31 / 9 / 11$ 